\title{
Strategi Penyelenggaraan Program Sekolah Ramah Anak: Analisis Peran Kepala Sekolah di SD Tanjung Jabung Timur Jambi
}

\author{
Syamsul Huda ${ }^{1 *}$, Dian Nisa Istofa ${ }^{2}$, \& Farida ${ }^{3}$ \\ Universitas Islam Negeri Sulthan Thaha Saifuddin, Jambi \\ *corresponding author: syamsulhuda@uinjambi.ac.id
}

\begin{abstract}
:
This research aims to describe the strategy of the principal in organizing a child-friendly school program at SDN 9/X Sido Mukti. This research uses descriptive qualitative methods. Data collection is done through observation, interviews, and documentation. Data analysis uses data reduction, data presentation, and drawing conclusions, and verification. The results showed that the implementation of child-friendly school programs began with child-friendly school program planning activities in accordance with SOPs and predetermined policies. The preparation of strategies to meet 6 indicators includes child-friendly school policies, the implementation of learning processes, facilities and infrastructure, trained educators and education personnel children's rights, child participation as well as parents and communities.
\end{abstract}

KEYWORDS: Management; leadership role; Child-friendly school programs.

\begin{abstract}
ABSTRAK:
Penelitian ini bertujuan untuk mendeskripsikan strategi kepala sekolah dalam menyelenggarakan program sekolah ramah anak di SDN 9/X Sido Mukti. Penelitian ini menggunakan metode kualitatif deskriptif. Pengumpulan data dilakukan melalui observasi, wawancara, dan dokumentasi. Analisis data menggunakan reduksi data, penyajian data, serta menarik kesimpulan, dan verifikasi. Hasil penelitian menunjukkan penyelenggaraan program sekolah ramah anak dimulai dengan kegiatan perencanaan program sekolah ramah anak sesuai SOP dan kebijakan yang telah ditentukan. Penyusunan strategi memenuhi 6 indikator meliputi kebijakan sekolah ramah anak, pelaksanaan proses pembelajaran, sarana dan prasarana, pendidik dan tenaga kependidikan yang terlatih hak anak, partisipasi anak serta orang tua dan masyarakat.
\end{abstract}

KATA KUNCI: Manajemen; peran kepemimpinan; program sekolah ramah anak.

Copyright @ Published by Program Studi Manajemen Pendidikan Islam Fakultas Tarbiyah dan Keguruan

Universitas Islam Negeri Sulthan Thaha Saifuddin jambi

Mendalo Darat, Muaro Jambi, 36361, Indonesia 


\section{PENDAHULUAN}

Pemilihan sekolah merupakan hal yang penting diperhatikan oleh para orang tua dengan memperhatikan kualitas mutu, visi-misi yang jelas, serta tenaga pendidik dan kependidikan yang professional sesuai dengan bidang dan keahliannya. Banyaknya fenomena kekerasan terhadap anak di bawah umur menjadi salah satu kekhawatiran orang tua siswa dalam pemilihan sekolah. Terjadinya kekerasan seperti bullying, kekerasan seksual terhadap anak dan perilaku yang menyimpang lainnya kini kerap terjadi baik di lingkungan sekolah maupun di luar lingkungan sekolah.

Pemilihan sekolah sangat berpengaruh dalam pembentukan karakter siswa dan proses kegiatan belajar siswa. Pada usia dasar, salah satu pendidikan yang dapat menjadi alternatif pilihan ialah Sekolah Ramah Anak (SRA). SRA memberi jalan keluar terhadap peniadaan kekerasan berbasis sekolah. Pendidikan ramah anak menempatkan pendidikan karakter pada jenjang pendidikan dasar sebagai dasar membangun karakter siswa. SRA menjadi satuan lembaga pendidikan fomal, nonformal, dan informal yang aman, bersih, dan sehat, serta peduli pada budaya lingkungan hidup, mampu menjamin, memenuhi, dan menghargai hak anak terhadap perlindungan anak dari kekerasan, diskriminasi, dan perlakuan salah.

SRA adalah salah satu program yang diselenggarakan oleh pemerintah Indonesia. Dalam Peraturan Menteri Negara Pemberdayaan Perempuan dan Perlindungan Anak Republik Indonesia Nomor 8 tahun 2014 tentang Kebijakan Sekolah Ramah Anak, dijelaskan bahwa dalam mewujudkan Sekolah Ramah Anak (SRA) ada enam indikator yang dikembangkan untuk mengukur capaian SARA. Indikator tersebut meliputi: 1) kebijakan SRA, 2) pelaksanaan kurikulum, 3) pendidikan dan tenaga kependidikan terlatih hak-hak anak, 4) sarana dan prasarana SRA, 5) partisipasi anak, dan 6) partisipasi orang tua, lembaga masyarakat, dunia usaha, pemangku kepentingan lainnya, dan alumni. Idealnya keenam indikator tersebut harus dipenuhi dalam rangka mewujudkan SRA.

Kebijakan dilansir oleh Kementerian Pemberdayaan Perempuan dan Perlindungan Anak Republik Indonesia (KemenPPPA) bertujuan untuk dapat memenuhi, menjamin dan melindungi hak-hak yang dimiliki oleh anak. 
Tujuan lainnya adalah memastikan bahwa sekolah mampu mengembangkan minat, bakat dan kemampuan anak serta mempersiapkan anak untuk bertanggung jawab kepada kehidupan yang toleran, saling menghormati, bekerja sama untuk kemajuan dan semangat perdamian. Hal ini dilakukan pada Sekolah Dasar Negeri 99/X Sidomukti, yang mendaftarkan sekolahnya untuk mengikuti program Sekolah Ramah Anak.

Dalam pengamatan penulis terhadap program SRA di SDN 99/x Sidomukti menempatkan pendidikan karakter pada jenjang pendidikan dasar sebagai membangun karakter siswa. SDN 99/X Sidomukti ini menjadi salah satu lembaga pendidikan formal yang aman, bersih dan sehat, serta peduli pada budaya lingkungan hidup, serta mampu menjamin, memenuhi dan menghargai hak anak terhadap perlindungan anak dari kekerasan, diskriminasi dan perlakukan salah. Sekolah diharapkan tidak hanya melahirkan generasi yang cerdas secara intelektual, namun juga melahirkan generasi yang cerdas secara emosional dan spiritual.

Program SRA telah diselenggarakan sejak tahun 2020 di SDN 99/X Sidomukti. Namun pada kondisi yang terjadi di SDN 99/X Sidomukti saat ini masih belum sesuai dengan kondisi yang diharapkan dan belum memenuhi dari enam indikator yang tercantum dalam Peraturan Menteri Negara Pemberayaan Perempuan dan Perlindungan Anak Republik Indonesia Nomor 8 Tahun 2014 tentang Kebijakan Sekolah Ramah Anak, diantaranya sarana dan prasarana untuk menunjang pelaksanaan program SRA masih belum memadai, tenaga pendidik dan tenaga kependidikan masih belum terlatih terhadap memahami hak-hak anak seperti melantarkan siswa dalam jam pelajaran berlangsung, serta kurangnya partisipasi siswa terhadap program SRA.

SRA diperkenalkan pada tahun 1999 oleh Bagian Pendidikan Kantor Program UNICEF di New York. Kerangka kerja SRA merupakan kerangka kerja yang didasarkan pada prinsip hak-hak anak sebagaimana tertuang dalam Konvensi Hak Anak (1990) dan instrumen hak asasi manusia internasional dan deklarasi internasional, termasuk Deklarasi Pendidikan untuk semua (1990). Pendekatan ini dimaksudkan untuk meningkatkan efektivitas pembelajaran, efisiensi dan jangkauan sistem pendidikan serta untuk memungkinkan semua anak menyadari hak untuk belajar. 
Pendidikan Ramah Anak dapat dimaknai sebagai suatu lembaga pendidikan yang dapat memfasilitasi dan memberdayakan potensi anak. Hal ini dapat dilakukan dengan memprogramkan sebuah rancangan pembelajaran yang menumbuh kembangkan seluruh potensi anak serta dapat melibatkan anak berpartisipasi dalam kehidupan sosial dan budaya, keluarga dan masyarakat tanpa menjadi pelaku dan korban tindak kekerasan serta diskriminasi. Kebijakan Sekolah Ramah Anak di Indonesia dikeluarkan oleh Menteri Negara Pemberdayaan Perempuan dan Perlindungan Anak Republik Indonesia Nomor 8 Tahun 2014 yang dimaksudkan sebagai acuan bagi pemangku kepentingan termasuk anak dalam mengembangkan SRA sebagai upaya untuk mewujudkan salah satu indikator Kota Layak Anak (KLA). Tujuan kebijakan Sekolah Ramah Anak adalah a) Memenuhi, menjamin, dan melindungi hak anak melalui lingkungan sekolah, b) Menjadi panduan kabupaten/kota dalam mengembangkan Sekolah Ramah Anak, dan c) Memenuhi salah satu indikator kabupaten/kota layak anak. Dalam kebijakan ini, memuat 6 (enam) komponen yang dikembangkan dalam Sekolah Ramah Anak. Keenam komponen tersebut meliputi 1) Kebijakan Sekolah Ramah Anak; 2) Pelaksanaan proses pembelajaran yang ramah anak; 3) Pendidikan dan tenaga kependidikan terlatih hak-hak anak; 4) Sarana dan prasarana Sekolah Ramah Anak; 5) Partisipasi anak; dan 6) Partisipasi orang tua, lembaga masyarakat, dunia usaha, pemangku kepentingan lainnya, dan alumni.

\section{METODE}

Penelitian ini menggunakan metode deskriptif kualitatif. Pengumpulan data kualitatif dilakukan melalui observasi, wawancara, dan dokumentasi. Adapun subjek penelitian ini adalah Kepala Sekolah SD Negeri 99/X Sidomukti. Dalam penelitian ini, peneliti menggunakan teknik purposive sampling, yaitu teknik pengambilan sampel sumber data dengan pertimbangan tertentu, misalnya orang tersebut dianggap paling tahu tentang apa yang diharapkan, atau mungkin sebagai penguasa sehingga akan memudahkan peneliti menjelajahi objek/situasi sosial yang diteliti (Sugiyono, 2010). Analisis data menggunakan teknik triangulasi pengujian kreadibilitas diartikan sebagai pengecekan data dari berbagai sumber dengan berbagai cara, dan berbagai waktu (Sugiyono, 2013). 


\section{HASIL PENELITIAN DAN PEMBAHASAN}

SD Negeri 9/X Sidomukti merupakan sekolah ramah anak yang mengupayakan pemenuhan hak dan perlindungan anak selama 8 (Delapan) jam berada di sekolah melalui upaya bersih, aman, ramah, indah, inklusif, sehat, asri dan nyaman. Program SRA menunjukkan pentingnya pendidikan ramah anak dalam keluarga. Maraknya kekerasan di dalam sebuah keluarga terhadap anak sangat diperlukan adanya penguatan-penguatan dalam keluarga untuk membangun pendidikan ramah anak dan menerapkannya dalam kehidupan sehari-hari.

Dalam tahap perencanaan, strategi kepala sekolah adalah melakukan inovasi terkait berbagai kegiatan yang mendukung terwujudnya program SRA. Kepala sekolah bersama tim merencanakan kesinambungan program dan kerja sama menyusun skema pengembangan SRA ke dalam RKAS dengan jejaring, khususnya dengan Dinas Pendidikan atau lembaga yang sudah mempunyai program yang berbasis sekolah dan program tersebut yang mendukung SRA, seperti Sekolah Adiwiyata, Sekolah/Madrasah Aman Bencana, Sekolah Bencana, Sekolah Tanpa Kekerasan, dan lain sebagainya.

Perencanaan program yang telah diajukan telah sesuai dengan kondisi lingkungan dan warga sekolah. SRA menjadi salah satu program yang dapat menonjolkan dan meningkatkan kualitas sekolah. Pelaksanaan kebijakan program SRA harus memenuhi beberapa komponen seperti adanya kelengkapan sarana dan prasarana, partisipasi anak, partisipasi orang tua dan partisipasi masyarakat. Pelaksanaan kebijakan program SRA sebaiknya melibatkan semua warga sekolah, dan kelengkapan sarana dan prasarana yang memadai, kurikulum yang sesuai dan tenaga kependidikan yang terlatih hak anak. Pemenuhan pelaksanaan program SRA dilihat dari adanya komitmen yang kuat oleh semua pihak yang ditulis dalam bentuk ikrar untuk mencegah kekerasan terhadap anak yang disusun secara bersama-sama yang dituangkan dalam SK internal sekolah (SK Tim Pelaksanaan dan Tim Pengembang SRA yang melibatkan semua warga satuan pendidikan diantaranya adalah peserta didik, pendidik dan tenaga kependidikan. 
Komitmen-komitmen lain yang mendukung program SRA yaitu:

1. Memiliki komiten untuk menerapkan prinsip-prinsip SRA dalam manajemen berbasis sekolah dan RKAS, hal ini dapat dilihat dari adanya sosialisasi mengenai RKAS oleh kepala sekolah.

2. Memilki komitmen untuk mewujudkan kawasan tanpa rokok. Komitmen ini dapat dilihat dari poster yang dipajang di salah satu lorong utama menuju kelas belajar.

3. Memiliki komitmen untuk mewujudkan kawasan bebas napza. Komitmen ini dapat dilihat melalui kegiatan sosialisasi dari BNN mengenai napza.

4. Memilki komitmen untuk menerpakan sekolah/madrasah aman dari bencana secara structural dan nonstructural. Komitmen ini dapat dilihat dari portofolio SRA dengan Adanya kerjasama sekolah dengan kepolisian dan pemadam kebakaran untuk melakukan simulasi bencana agar siswa dapat memahami cara evakuasi dari bencana.

5. Pemenuhan kebijakan SRA dalam penerapannya harus memiliki kebijakan anti kekerasan (baik oleh sesama siswa, tenaga pendidik dan kependidikan, termasuk oleh pegawai sekolah lainnya).

Adanya beberapa poster larangan terhadap tindak kekerasan dan diskriminasi antar peserta didik, pendidik dan tenaga kependidikan. Larangan tersebut diantaranya: 1) Larangan terhadap tindak kekerasan dan deskriminasi antar peserta didik (bullying), pendidik dan tenaga kependidikan (TU, penjaga sekolah dan petugas kebersihan), 2) Larangan hukuman badan (yaitu memukul, menampar dengan tangan/cambuk/tongkat/ikat pinggang/sepatu/balok kayu, menendang, melempar peserta didik, mencubit, mengigit dan lain sebagainya, 3) Larangan dalam bentuk hukuman lain yang merendahkan martabat peserta didik (menghina, meremehkan, mengejek, dan menyakiti perasaan dan harga diri peserta didik) oleh penididik terhadap peserta didik, maupun hukuman lainnya yang mereduksi hak anak untuk mendapatkan pendidikan (misalnya: mengeluarkan peserta didik dari sekolah, melarang peserta didik masuk ke dalam lingkungan sekolah karena terlambat atau sebab lainnya). Proses pembelajaran menitikberatkan kepada hak setiap anak untuk menyatakan pendapatnya, menerima, mencari dan memberikan informasi sebagai upaya pengembangan dirinya. Selain itu, pembelajaran juga memberikan kesempatan kepada anak untuk menikmati pendidikan tanpa 
deskriminasi berdasarkan disabilitas, gender, suku bangsa, agama, dan latar belakang orang tua.

\section{SIMPULAN}

Penyusunan strategi yang dilakukan oleh kepala sekolah dalam penyelenggaraan program SRA di SDN 99/X Sidomukti merupakan tahapan awal dalam membuat keputusan dan tindakan yang dibuat oleh manajemen puncak dan diimplementasikan oleh seluruh jajaran suatu organisasi dalam rangka pecapaian tujuan organisasi. Upaya yang dilakukan oleh kepala sekolah dalam penyelenggaraan program SRA ini adalah untuk menjamin pemenuhan hak anak dan perlindungan anak dari kekerasan serta berada pada lingkungan yang aman, bersih, sehat, peduli dan berbudaya. Dengan pengelolaan serta kerja sama antar tim yang baik akan menjamin keberhasilan dalam pelaksanaan program SRA tersebut sesuai dengan indikator dan komponen pada kebiajakan SRA.

Penerapan program SRA telah dilaksanakan dengan menerapkan 6 (enam) komponen SRA diantaranya adalah kebijakan SRA, pelaksanaan proses pembelajaran, sarana dan prasarana, pendidik dan tenaga kependidikan yang terlatih hak anak, partisipasi anak serta partisipasi orang tua dan masyarakat kepengan lainnya. Pemenuhan penerapan program SRA dapat dilihat dari adanya komitmen yang kuat dari semua pihak yang di tuangkan dalam SK tim pelaksanaan dan tim pengembangan SRA yang melibatkan semua guru, warga satuan pendidikan diantaranya adalah peserta didik, pendidik dan tenaga kependidikan.

\section{REFERENSI}

Hajaroh, Mami. dkk. (2017). Analisis Kebijakan Sekolah Ramah Anak Dikawasan Pesisir Wisata. Yogyakarta: C.V ANDI.

Idris, Ridwan. (2014). Manajemen Pendidikan dalam Aplikasinya di Sekolah. Makassar: Alauddin University Press.

Masyhud, M. Sulthon. (2007). Modul Pengembangan Profesi Kependidikan Bagi Pengawas Sekolah. Jember: FKIP Universitas Jember.

Masyhud, Sultan. (2014). Manajemen Profesi Kependidikan. Yogyakarta: Kurnia Kalam Semesta.

Munjianto. (2017). 'Rencana Sertifikasi dan Konsorsium Tenaga Kependidikan.” Jurnal Tenaga Kependidikan, 1(1). 
Moleong, Lexy J. (2007). Metode Penelitian Kualitatif. Bandung: Remaja Rosdakarya.

Nilasari, Senja. (2014). Manajemen Strategi Itu Gampang. Jakarta Timur: Dunia Cerdas.

Peraturan Menteri Negara Pemberdayaan Perempuan dan Perlindungan Anak Republik Indonesia Nomor 8 Tahun 2014 tentang Kebijakan Sekolah Ramah Anak.

Prasojo, Lantip Diat. (2018). Manajemen Strategi. Yogyakarta: UNY Press.

Sanjaya, Wina. (2008). Kurikulum dan Pembelajaran. Jakarta: Prenada Media Group.

Sedjati, Retina Sri. (2019). Manajemen Strategis. Yogyakarta: Deepublish.

Sugiono. (2014). Metode Penelitian Kuantitatif, Kualitatif, dan REBB. Bandung: Alfabeta. 